\title{
The contribution of social conflict with peers toward self-confidence
}

\author{
Indah Octaviyana1, Firman², Daharnis ${ }^{3}$ \\ ${ }^{123}$ Universitas Negeri Padang, Padang - Indonesia, (indah23octaviyana@yahoo.co.id)
}

\begin{abstract}
Some students still have less self-confidence. Students' self-confidence is thought to be related to social conflict with peers. The study aims to describe the contribution of social conflict with peers toward self-confidence. This research used quantitative approach with descriptive-correlational method. The population of this research are high school students Pringsewu Lampung, with sample 280 students using propotional stratified random sampling. Data collection using questionnaire with Likertscale model, with instrument reliable: social conflict with peers 0.843 and students' self-confidence 0.878 . Data were analyzed using simple regression. The results of the research shows that the social conflict with peers contributed $(7.7 \%)$ toward students' self-confidence.
\end{abstract}

Keywords: social conflicts, self confidence, peer conflicts, senior high school

\section{Introduction}

Self-confidence is an aspect of personality that serves as a means to actualize their potential. Low self-confidence can lead to a variety of obstacles in carrying out activities. Confidence is needed by students to facilitate the learning process in schools. Self-confidence is a person's belief about all aspects of the advantages and beliefs are able to achieve various objectives in life (Judge, T., 2004; Komara, I. B., 2016; Marjanti, S., 2015; Nurbayani, S., Yuliasma, Y., \& Asriati, A., 2017).

Self-confidence is very important, especially when students are given the task by the teacher. Besides, self-confidence is also needed to socialize with peers. Someone who has high self-confidence will feel optimistic in achieving something as expected. Conversely, a person who lacks the ability, negative assessments regarding the ability to inhibit efforts will be done to achieve the objectives to be achieved. (Warman, 2013; Latumahina, M. F. S., Musyafa, S., \& Sons, N. S., 2000; Husna, A. N., NRH, F., \& NRH, F., 2017).

At the time in adolescent schools began to learn to develop social interaction by learning to accept views, values, and social norms. Social development in adolescence more involving peer groups than parents, teenagers do more activities outside the home such as school activities, extracurricular, and play with friends (Conger, Papalia, \& Olds, 2001; Hidayat, OS, 2014; Permana, BC , 2015). In these activities, teenagers generally do more activities with peers. Students always try to gain recognition from their friends both men and women (Tohirin, 2015; Sari, JF, Karsih, K., \& Tjalla, A., 2014; Maulana, A., Suryadi, K., \& Syam , S., 2015).The pattern of teenagers life that is different from adult groups and groups of children can lead to social conflict. This is in accordance with the opinion of some psychologists who claimed that youth are vulnerable to the emergence of various conflicts ( Khasanah, P., 2014; Siregar, B. G., 2015). Adolescents who experience social conflicts do not feel 
confident in their activities. Data obtained during the month of August 2016 occurred more than 44 conflict one of them fights and brawls (School Notes, 2016).

Based on the above description, it can be assumed that students' self-confidence is influenced by social conflicts with peers. This is evident from the many students who experience conflict or problems with peers, thus making students less self-confident and less good relations with peers.

\section{Methods}

This type of research is quantitative approach descriptive, correlational. The sample in this study amounted to 280 students. Data collection tool that is used in the form of a questionnaire Likert scale models.

\section{Results and Discussion}

The data in this study included the variables of social conflicts with peers (X1) and the confidence of the student $(\mathrm{Y})$. Here's a description of the research data.

\section{Social Conflict with Peers}

The results showed that of the total sample of 280 students, the majority of social conflicts with peers that are in the low category with the number of frequency of 230 students, or as big as $82.14 \%$ and a small portion of social conflicts with peers in middle category with the number of frequencies 33 students or as big as $11.79 \%$ and a very low number of frequencies of 17 students or as big as $6.07 \%$.

\section{Self-Confidence}

The results showed that of the total sample of 280 students, most students have a high selfconfidence with the number of frequency of 224 students or as big as $80 \%$ and some others have a very high self-confidence with the number of frequency of 6 students or as big as $2.14 \%$ and being the number of frequency of 50 students or as big as $17.86 \%$.

\section{Testing Requirements Analysis Data}

Test requirements analysis undertaken in this study is a test for normality, linearity test, and a test multicollinearity. Normality test results showed normal distribution of data. Furthermore, the test results are known data are expressed linear linearity. Then, the test results do not happen multikolinieritas multikolinieritas show.

\section{Hypothesis testing}

The Contribution of Social Conflict with Peers on Confidence Students

The results of the analysis of the contribution of social conflicts with peers on students 'selfconfidence shows that the $\mathrm{R}$ value of 0.278 indicates regression coefficient between social conflicts with peers on students' self-confidence, with a significant level of 0.000 . R Square (R2) of 0.077 , this means social conflicts with peers accounted for $7.7 \%$ of the students' self-confidence, while the remaining $92.3 \%$ is explained by other variables.

Social Conflict with Peers

The results of data analysis showed that the overall average social conflicts with peers that are in the low category. This means that overall the students were able to establish social relationships so well that social conflict experienced by students with peers in school is low. Social conflicts with peers that are in the low category would still need to reduce and eliminate social conflicts that occur in schools, given the ever-expanding social relationships by adolescents, the more teens are dealing with the patterns are different, their individual differences, perspectives, behavior, interests, and so forth can cause conflicts with peers (Pohan, 2015; Wartini, S., 2016; Santosa, E., \& Budiati, L., 2014; Royani, A., 2016). 
Next, look in detail the results of the data analysis, social conflicts with peers on indicators of disagreements with friends having the highest percentage of $50.8 \%$. The lowest percentage is at enmity with the percentage indicator of $33.4 \%$, lower than any other indicator, although the overall percentage of each indicator is not too much different.The highest percentage of disagreements with friends indicators show that there are still some students who often have debates due to disagreements with friends. Related to disagreements with friends, Wahyudi explained the nature of the conflict of students in schools, among others such as disagreements, conflicts, the emergence of disputes in achieving its objectives, there is hostility, preclude another party to obtain victory, debate and disagreement as a result of the emergence of creativity, initiative, or new ideas (Wahyudi, 2008; Nst, H. A., 2014; Khasanah, P., 2014; Sukarno, B., 2015).Conversely, the lowest percentage in hostilities indicators show that there are students who are having problems and hostile with their peers. Conflict in teens are caused by problems with his friend, in an effort to protect themselves from anxiety, then a teenager doing externalizing defense with aggressive behavior, err, and other mischief (Praptiani, 2013; Arni, I., 2016; Hammi, I., 2017).

Social conflicts with peers can be said as a result of a situation or condition where there is a desire in the opposite or different from each other so that one or both of them to be disturbed. Life filled with tension and conflict will make teenagers feel confident in conducting all its activities, so that adolescents can not develop their potential optimally. Teenagers who failed in addressing the problems often lack confidence, decreased school performance, relationships with friends become less good as well as a variety of problems and other conflicts (Puspita, 2014; Santoso, A. D., 2015; Sudjiwanati, S., 2017).

\section{Student Self-Confidence}

The results of data analysis showed that the overall average self-confidence of students at the high category. This means that students have good self-confidence. The self-confidence of students in higher categories would need to be maintained and further enhanced, given the self-confidence of an individual positive attitude that enables him to develop a positive assessment, both to themselves and to the environment / situation he faced (Fatimah, E., 2010; Weni, A., 2015; Haeruman, L. D., Rahayu, W., \& Ambarwati, L., 2017).

Next, look in detail the results of the data analysis, the self-confidence of students in the optimistic and rational attitude indicator had the highest percentage of $80 \%$. The lowest percentage was the indicator of the ability of self with the percentage of $67.9 \%$, lower than any other indicator, although the overall percentages in each of the indicators are not much different. The high percentage of the optimistic and rational attitude indicator indicates that the student has an optimistic attitude in the face of a problem and the rational in view of a case in accordance with reality. Teens who are confident have the self-confidence to do something in the subject as a personal characteristic in which there is confidence in the ability of self-esteem, optimism, objective, responsible, rational, and realistic(Ghufron,M. N,\& Risnawita, R., 2014; Komara, I. B., 2016; Santoso, A. D., 2015).Conversely, the lowest percentage in the indicator of the ability of self shows that students are less confident with the ability itself. Low self-confidence tend to be difficult to accept the reality of self (especially receiving shortcomings) and look down capability themselves, but on the other hand, put up unrealistic expectations of yourself (Fatimah, E., 2010; Gapi, B., 2015; Pritama, D., 2015).

Self-confidence can be regarded as a belief of a person against all the advantages it has and that belief makes him feel capable of achieving goals in his life. A person who has high self-confidence if he is able to make positive statements about himself, self-respect, and able to pursue expectations that are likely to make it successful. Conversely, individuals with low self-confidence will experience barriers in their life, either in interacting with others or in work (Hurlock, E.B., 2002; Ibnu Ardi, I.,2015; Marizka Adi Winarni, M., 2016; Syahrina, I. A., \& Andini, F. D., 2017). 
Contributions of Social Conflict with Peers towardStudents Self-Confidence

The results showed that social conflicts with peers to contribute significantly to the students' selfconfidence. The discovery was made based on sequence analysis of the data shows that the contribution of social conflicts with peers on students' self-confidence by $7.7 \%$. That is, the low social conflicts with peers contribute to the students' self confidence.The students' self-confidence in addition influenced by external factors, also affected by internal factors, internal factors may be of the self-concept factors, physical condition, and self-esteem. Another factor that can cause lack of selfconfidence is the mass media such as TV, radio, print media, the internet and even sometimes provide information that was not relevant (Iswindharmajaya, J.,2014; Amin, O. L. G., 2015; Ainina, I. A., 2014).Back to the results showed that social conflicts with peers to contribute significantly toward studentsself-confidence. This means that social conflicts with peers low, contributes to the high confidence of the students. Likewise, social conflicts with peers higher, result in low students' selfconfidence.

\section{Conclusion}

On average the social conflicts of peers that are in the low category and confidence of students at the high category, as well as social conflicts with peers to contribute significantly to the confidence of students. That is, if social conflicts with peers who experienced high student, the student's confidence will be low, or vice versa when social conflicts with peers experienced by students is low, then the student's confidence will be higher.

\section{References}

Ainina, I. A. (2014). Pemanfaatan media audio visual sebagai sumber pembelajaran sejarah. Indonesian Journal of History Education, 3(1).

Amin, O. L. G. (2015). Representasi Kecantikan Perempuan pada Iklan Dove Versi "Real Beauty Sketches" di Situs Youtube. Universitas Airlangga: Jurnal, 73.

Arni, I. (2016). Pengaruh Sensation Seeking melalui Kontrol Diri terhadap Kenakalan Remaja Di SMKN 2 Depok (Doctoral dissertation, Universitas Bhayangkara Jakarta Raya).

Iswindharmajaya, D. J. (2014). Satu Hari Menjadi Lebih Percaya Diri. Elex Media Komputindo.

Fatimah, E. (2010). Psikologi Perkembangan (Perkembangan Peserta Didik). Bandung. Pustaka Setia.

Gapi, B. (2015, June). Membangun Kepercayaan Diri Siswa melalui Kegiatan Ekstrakurikuler. In Prosiding Seminar Nasional Pendidikan Ekonomi FE UNY" Profesionalisme Pendidik dalam Dinamika Kurikulum Pendidikan di Indonesia pada Era MEA". Fakultas Ekonomi UNY.

Ghufron, M. N. \& Risnawita, R. (2014). Teori-teori Psikologi. Yogjakarta. Ar-Ruzz Media.

Haeruman, L. D., Rahayu, W., \& Ambarwati, L. (2017). Pengaruh Model Discovery Learning terhadap Peningkatan Kemampuan Berpikir Kritis Matematis dan Self-Confidence Ditinjau dari Kemampuan Awal Matematis Siswa SMA di Bogor Timur. Jurnal Penelitian dan Pembelajaran Matematika, 10(2).

Hakim, T. (2004). Mengatasi Rasa Tidak Percaya Diri. Jakarta. Puspa Swara.

Hammi, I. (2017). Hubungan Pola Asuh Orang Tua dan Faktor Lingkungan Sekolah Terhadap Kejadian Perilaku Agresif pada Anak Usia Sekolah (Doctoral dissertation, Universitas Muhammadiyah Purwokerto).

Hidayat, O. S. (2014). Metode Pengembangan Moral dan Nilai-nilai Agama.

Hurlock, E. B. (2002). Psikologi Perkembangan: Suatu pendekatan sepanjang rentang kehidupan. Alih Bahasa Istiwidiyanti dan Soedjarwo. Jakarta. Airlangga.

Husna, A. N., Nrh, F., \& Nrh, F. (2017). Regulasi Diri Mahasiswa Berprestasi. Jurnal Psikologi Universitas Diponegoro. 
Ibnu Ardi, I. (2015). Hubungan Antara Kepercayaan Diri Dengan Penyesuaian Sosial Pada Siswa Kelas X Di Smk Negeri 1 Kalasan (Doctoral Dissertation, Fakultas Ilmu Pendidikan).

Khasanah, P. (2014). Meningkatkan Kemampuan Manajemen Konflik melalui Konseling Kelompok. Psikopedagogia Jurnal Bimbingan dan Konseling, 3(2), 67-77.

Komara, I. B. (2016). Hubungan antara Kepercayaan Diri dengan Prestasi Belajar dan Perencanaan Karir Siswa SMP. Psikopedagogia Jurnal Bimbingan dan Konseling, 5(1), 33-42.

Marizka Adi Winarni, M. (2016). Efektivitas Konseling Realitasuntuk Meningkatkan Penerimaan Diri Siswa Kelas Ix Di Smp Negeri 1 Tempel Tahun Ajaran 2016/2017 (Doctoral dissertation, Fakultas Ilmu Pendidikan).

Marjanti, S. (2015). Upaya Meningkatkan Rasa Percaya Diri melalui Konseling Kelompok Bagi Siswa XII IPS 6 SMA 2 Bae Kudus Tahun Pelajaran 2014/2015. Jurnal Konseling Gusjigang, 1(2).

Maulana, A., Suryadi, K., \& Syam, S. (2015). Penggunaan Media Sosial Path sebagai Sarana Pengakuan Sosial. Sosietas, 5(2).

Nst, H. A. (2014). Efektifitas Layanan Konseling Kelompok dalam Mengatasi Konflik antar Kelompok Siswa di Sma Negeri 5 Pekanbaru (Doctoral Dissertation, Universitas Islam Negeri Sultan Syarif Kasim Riau).

Permana, B. C. (2015). Perbedaan Nilai-Nilai Sosial pada Peserta Didik yang Mengikuti Ekstrakurikuler Olahraga dengan Peserta Didik yang Mengikuti Ekstrakurikuler Non Olahraga di SMA Negeri 3 Yogyakarta (Doctoral dissertation, Fakultas Ilmu Keolahragaan).

Praptiani, P. (2013). Pengaruh Kontrol Diri terhadap Agresivitas Remaja dalam Menghadapi Konflik Sebaya dan Pemaknaan Gender. Jurnal Sains dan Praktik Psikologi, 1 (1), 1-13.

Pritama, D. (2015). Studi tentang Upaya Guru dalam Meningkatkan Kepercayaan Diri Siswa SD Negeri 1 Pengasih (Doctoral dissertation, PGSD).

Royani, A. (2016). Manajemen Konflik. Edukasi, 7(1).

Santosa, E., \& Budiati, L. (2014). Manajemen Konflik.1-54

Santoso, A. D. (2015). Hubungan antara Kepercayaan Diri dengan Kompetensi Sosial pada Siswa SMP N 16 Surakarta (Doctoral dissertation, Universitas Muhammadiyah Surakarta).

Sari, J. F., Karsih, K., \& Tjalla, A. (2014). Hubungan antara Penyesuaian Diri dengan Kecenderungan Perilaku Cyber Bullying pada Siswa Kelas Viii Smp Labschool Jakarta Tahun Ajaran 2013-2014. Insight: Jurnal Bimbingan dan Konseling, 3(1), 70-76.

Siregar, B. G. (2015). Solusi dalam Menghadapi Permasalahan Remaja. Hikmah: Jurnal Ilmu Dakwah dan Komunikasi Islam, 7(1), 100-116.

Sudjiwanati, S. (2017). Manajemen Konflik terhadap Kekebalan Stres Remaja Sekolah Menengah Kejuruan. Psikovidya, 18(2).

Sukarno, B. (2015). Komunikasi dan Pengendalian Konflik dalam Politik. Transformasi, 1(26).

Syahrina, I. A., \& Andini, F. D. (2017). Self Confidence Hubungannya Dengan Academic Dishonesty Pada Mahasiswa Fakultas Ilmu Komputer Universitas X. Psikovidya, 21(1), 1-12.

Tohirin. (2015). Bimbingan dan Konseling di Sekolah dan Madrasah (Berbasis Integrasi). Jakarta. Rajawali Pers.

Wartini, S. (2016). Strategi Manajemen Konflik sebagai upaya Meningkatkan Kinerja Teamwork Tenaga Kependidikan. Jurnal Manajemen dan Organisasi, 6(1), 64-73.

Weni, A. (2015). Implementasi Kegiatan Ekstrakurikuler Muhadlarah dalam Meningkatkan Kepercayaan Diri Siswa Madrasah Ibtidaiyah Mamba'ul Huda Al-Islamiyah Ngabar Ponorogo tahun plajaran 2014/2015 (Doctoral dissertation, STAIN Ponorogo).

Nurbayani, S., Yuliasma, Y., \& Asriati, A. (2017). Menumbuhkan Kreativitas Anak Tunarungu dalam Kegiatan Pengembangan Diri Seni Tari di SLB Negeri 2 Padang. Sendratasik UNP, 6(1), 18-27. 